\title{
KONTEKS SEJARAH MARITIM INDONESIA DALAM NOVEL ARUS BALIK KAYA PEMOEDYA ANANTA TOER KAJIAN NEW HISTORISM
}

\author{
Kumaidi \\ SDN Kujung Kec. Widang Kab. Tuban \\ Jl. Masjid Jami’ No.O2 Desa Kujung \\ Pos-sel: kumaidi07@gmail.com \\ 085730035228
}

\begin{abstract}
Abstrak: Karya sastra mempunyai struktur yang terjalin dari manusia dan kemasyakaratannya. Sehingga karya sastra lahir mencerminkan kondisi sosial masyarkat yang melingkupinya. Dalam perkembangannya, baik disiplin ilmu kesastraan juga menawarkan segala macam perspektif yang mampu membedah karya sastra dewasa ini. begitu juga Stepheend Greenblat yang menawarkan perspektif baru dengan pendekatan NewHistorism. Dalam kajian New Historism yang kan membedah kontteks sejarah dalam Novel Arus Balik karya Pramoedya Ananta Toer. Data yang akan diperoleh dalam Novel nanti berupa teks sejarah yang mendukung karya sastra itu lahir. Hasil dari penelitian yang menggunakan metode diskrptif kualitatif yang pada rumusan masalah yang pertama menunjukan bahwa, kemaritiman Indonesia mempunyai peranan yang sangat fital dalam mempertahankan suatu wilayah atau kekuasaan suatu Negara. Kemaritiman yang identik dengan laut merupakan salah satu sumber kehidupan bagi Negara seperti halnya Indonesia. laut juga mempunyai makna secara filosofis, yaitu dengan mendidik generasi dengan kekauatan laut serta mempunyai wawasan tentang kelautan yang bagi Indonesia laut lebih luas daripada darat.
\end{abstract}

Kata kunci: Sejarah Maritim Indonesia, Novel, New Historism

Abstract: The literary work has a structure woven from human and kemasyakaratannya. So that literary works were born reflect social conditions surrounding community. In the process, both literary disciplines also offer all kinds of perspectives able to dissect literature today. so also Stepheend Greenblat that offer a new perspective with the approach of New Historism. In a study of New Historism which dissects the history kontteks in Novel Reverse Flow works of Pramoedya Ananta Toer. The data will be obtained in a later novel in the form of a history text that supports the literature was born. Results of studies using qualitative methods diskrptif the formulation of the first to show that, maritime Indonesia has a very vital role in maintaining a region or a state authority. Maritime identical with the sea is a source of life for countries like Indonesia. Sea also has a philosophical meaning, that is by educating the next generation with sea and have insight into the Indonesian marine sea wider than the land.

Keywords: maritime history Indonesia, novel, new historism 


\section{PENDAHULUAN}

Karya sastra sebagai ilmu dan pengetahuan (Teuww, 1988:173), menyebutkan antara fakta dan rekaan. Salah satu cirikas karya sastra adalah rekaan yang bersifat imajinatif, pengarang memadukan antara fakta dan khayalan atau disebut mimesis dan creatio. Dari sinilah dibutuhkan penelitian, sehingga karya sastra akan nampak sebagai dokumen sosial yang sudah di bumbui oleh sang hero yang tidak terlepas dari konteks sosial sang pengarang dimana karya sastra dilahirkan dalam waktu tertentu. Dari sinilah (Teuww, 1988:173), juga menyebutkan bahwa karya sastra sebagai reaksi atas dinamika sosial yang melatarbelakangi lahirnya karya sastra atau ide kreatif dari pengarang.

Karya sastra terlahir tidak serta merta lahir begitu saja. Namun ada beberapa permaslahan yang melingkupi karya sastra itu lahir. Permasalahan baik sosial, budaya, maupun politik. Maka karya sastra pada zaman ini banyak karya-karya sastra yang mengandung unsur-unsur eks yang melingkupi pengarang. Melalui karya sastra inilah pengarang mengambil sikap dari konflik sosial yang berada dalam masyarakat tersebut (Faruk, 2012:93).

Berdasarkan latar belakang tersebut, penelitian ini memfokuskan kajiannya pada sastra maritim Indonesia yang terdapat dalam novel arus balik karya Pramoedya Ananta Toer. Masalah tersebut akan dipahami dengan pendekatan NewHistorism. Hal yang mendasari memilih pendekatan tersebut, adanya unsur sejarah yang melingkupi karya Pramoedya yang cenderung pada sisi kemaritiman pada masa kerajaan Majapahit yang di sebut dengan Nusantara.

Bersadarkan paparan di atas, perlu adanya penelitian yang bertujuan untuk mendiskripsikan konteks sejarah maritim Indonesia dalam Novel Arus Balik karya Pramoedya Ananta Toer.

\section{METODE}

Rancangan penelitian pada karya sastra sangat beragam dan berbeda-beda. Jika dikaitkan dengan tujuan penelitian, ada dua macam penelitian. Yaitu, penelitia lapangan dan penelitian perpustakaan. Penelitian lapangan dilakukan dalam kaitannya dengan objek penelitian yang memanfaatkan kejadian langsung. Sedangkan untuk penelitian pustakaan dilakukan dalam kaitannya dengan objek dalam bentuk karya tertentu (Ratna, 2012:17).

Meskipun dalam penelitian ini, karya sastra sebagai objek penelitian, namun memiliki teori dan metode yang berbeda. Karya sastra sebagai objek penelitian, metode dan teori sebagai cara untuk meneliti. Dalam penelitian ini yang menjadi objek penelitian adalah karya sastra (novel) yang berjudul Arus Balik karya Pramoedya Ananta Toer dengan menggunakan metode atau pendekatan New Historism. Pendekatan New Historism (Setephent Grenblatt) termasuk dalam teori postrukturalisme (Barry, 2010:201).

Metode penelitian yang digunakan dalam kajian ini yakni dengan metode deskriptif kualitatif yang berusaha mendeskripsikan fenomena data berupa kata, frase, kalimat, atau wacana yang menggambarkan sejarah maritim Indonesia dalam perspektif new historicism.

Data dalam penelitian ini adalah karya sastra yang berupa novel, Novel yang berjudul Arus Blaik karya Pramoedya Ananta Toer. Buku sejarah yang selaras dengan sejarah yang melingkupi karya sastra tersebut. Beberapa jurnal penelitian yang telah ada. Buku-buku yang mengupas tentang 
karya-karya Pramoedya. Dan ditujang dengan buku-buku tentang biografi Prmoedya.

Data dan sumber data dalam penelitian akan dikelompokakn sesuai dengan rumusan masalah. Data tentang sejarah kemaritiman Indonesia yang tertuang dalam tek novel Arus Balik karya Pramoedya dan teks-teks sejarah yang telah ada. Dan data yang terkait dengan rumusan masalah kedua tentang Budaya yang tertuang dalam teks novel Arus Balik Pramoedya Ananta toer.

Data berupa kata, frase, kalimat, dan satuan cerita yang diambil dari novel dan teks sejarah yang menjadi objek penelitian. Di samping itu juga dikumpulkan data yang berhubungan dengan novel arus balik dan sejarah. Data tersebut di catat dan diklasifikasi sesuai denagn informasi yang berhubungan dengan masalah peneliti (Ratna, 2012:66).

\section{HASIL DAN PEMBAHASAN Konteks Sejarah Maritim Indonesia}

Pada bagian ini akan di jelaskan hal yang berkaitan langsung dengan sejarah kemaritiman Indonesia/Negara yang terdapat dalam teks sastra (novel). Semasa jayanya Majapahit, Nusantara mrupakan kesatuan maritim dan kejayaan laut terbesar di antara bangsa-bangsa di muka bumi. Pramoedya memaparkan maritim serta kekuatan laut yang menjadi tonggak kebesaran serta kesatuan sebuah kerajaan/Negara. Seperti kerajaan Majapahit, sejarah maritim yang dikembangkan sejak zaman Majapahit memiliki sejarah yang panjang terutama pada paulau jawa yang menjadi pusat kemaritiman Majapahit. luas wilayah jajahan Majapahit merupakan salah satu bukti atas kejayaan serta kemegahan yang dibangun oleh Majapahit melalui kekuatan luatnya.
Laut menjadi akses utama semenjak kerajaan Sriwijaya, Singosari, hingga Majapahit. Malalui jalur laut kerjaan mengembangkan sistem dagang serta laut menjadi akses utama dalam memperluas wilayah serta menjadi pertahanan bagi kerajaan. hal ini juga disampaikan oleh Pramoedya dalam novel arus balik yang mengambarkan kekeuatan maritim yang berada di pesisir laut Jawa. Teramsuk yang menjadi pusat setting dalam novel arus balik adalah Tuban.

Pelabuhan Tuban menjadi gerbang utama di pulau jawa. Dan pelabuhan di jawa timur pada abab ke XIII. Seperti yang di katakan oleh Soetopo dalam sejarah Tuban. Bahwa orang-orang kalau mau pergi ke jawa pasti kapal-kapal terdahulu bersandar pada bandar Tuban. Selain itu juga, Tuban menjadi andalan majapahit. Selain mepunyai bandar juga karena pasukan yang dimiliki oleh Tuban (Soeparmo, 1983:19).

Berdasarkan pendapat Soeparmo (1983) tersebut, dapat dipahami bahwa konteks sejarah kemaritiman Di Indonesia pada masa Kerajaan Majapahit tidak dapat dilepaskan dari pelabuhanpelabuhan besar yang ada pada saat itu, terutama pelabuhan Tuban. Dengan perkataan lain, pelabuhan Tuban memiliki peran penting di dalam pengembangan perdagangan dan akses keluar masuk kerajaan Majapahit. Oleh karena itu, pelabuhan Tuban kerap dijadikan daerah perebutan kekuasaan, peperangan, dan kerusuhan.

Tuban adalah wilayah yang tidak pernah tentram. Wilayah yang rawan dengan konflik. Konflik baik diri sendiri maupun konflik dari luar. Berbagai konflik yang pernah terjadi di bumi perbatasan yang terletak di utara laut Jawa. Termasuk juga Tuban sebagia gerbang utama kerjaan Singgosari dan juga Majapahit. Tuban menjadi bandar serta kekuatan andalan Majapahit, 
sehingga Tuban tidak hentinya-hentinya dirundung kekacauan.

Kota Tuban menjadi inti dari kekusaan Majapahit. Selain menjadi inti kerajaan Majaphit, Tuban juga menjadi pusat pertanahan kerjaan besar yang pernah ada Jawa ini. Jauh sebelum kerajaan Majapahit, salah satu bandar yang beada di Lao Sam juga pernah menjadi pusat orang-orang Tiongkok.

Pram mengambarkan kejayaan laut serta kerajaanya. Namun setelah pasca keruntuhan Majapahit, kegemilangan itu hanya sebatas angin yang lewat. Kondisi jawa serta lautnya mengalami perubahan yang segnifikan.

Perubahan yang di alami oleh pulau Jawa serta kerajaan yang berada di pesisir laut jawa, semkain terpuruk. Seperti cuplikan novel di atas. Hal ini juga di picu oleh jatuhnya Malaka sebagai kunci bandar seAsia Tengara ke Tangan Portugis. Tentang kejuatuhan Malaka juga tidak luput dari sebuah penghiatan seorang bandar Malaka yang bernama Sayid Habibullah Almasawa.

Jelas bagaimana Pramoedya menyebutkan atas buah dari pengkhianatan dari seseraorang syahbandar Malaka itu sendiri. Setelah Malaka jatuh, bnadar yang disebut sebagai bandar kunci Asia itu sekarang telah terjarah orang-orang peranggi.

Majapahit telah lama jatuh, manun intrik serta konflik baik dari dalam maupun luar juga tidak kunjung reda. Pembesar-pembesar jawa yang baerda di pesisir pulau jawa sudah luapa akan kekuatan laut yang begitur besar yang pernah dimiliki oleh Majapahit. Termasuk Tuban, kota yang telah di anugrai lima bandar besar justru malah sang Adipati tidak mau peduli dengan apa yang sudah dipunyai.

Bagaimana sikap seorang Bupati Tuban yang digambarkan oleh Pramoedya dalam novel ARB. Tuban pada waktu sudah menjadi sangat berbeda, begitu juga sang Adipati Arya Teja Tumenggung Wilwatikta. Ia tidak menghendaki Tuban menjadi kekaisaran benua seperti Majapahit dengan alasan terlalu banyak urusan.

Selain mengambarkan perdagangan yang dibagun di laut, Pramoedya juga menyebutkan betapa penting peranan laut bagi Nusantara Pramoedya menjelaskan bahwa bukan hanya tanah, seluruh alam diberikan oleh Allah pada manusia. Kalau orang tak tahu artinya alam. Inilah dia: semua-semua saja kecuali Allah sendiri. Tanah ini, jawa ini, kecil, lautnya besar. Barang siapa barang siapa kehilangan air, dia kehilangan tanah, barang siapa kehilangan laut dia kehiangan darat (Toer, 1995:223).

Jelas, bagaimana Pramoedya memberikan wacana tentang bumi dan laut. laut yang brperan sebagai sumber kehidupan. Namun, di zaman yang modren setelah pasca kemerdekaan, laut sudah tidak di nomer satuakan. Apalagi zaman orde baru, laut menjadi hal paling belakang dalam sistem pemeritahan. Laut hanya sebatas untuk transfortasi, wisata, dan untuk sebatas pencarian ikan bagi orang-orang pesisir.

Begitu juga kota Tuban, kota yang mempunyai laut yang membentang barat dan timur, serta bandar yang yang besar sekaligus sebagai kota yang memiliki bandar yang besar. Namun na' as, hal ini tidak di sadari oleh sang Adipatih Tuban. Di masa tuanya, ia ingin bertenga-tenang tanpa harus repot-repot memikirkan pertahanan di laut. juga tidak mau mengembangkan kekuatan laut. ia lebih memfokuskan pada perniagaan, dagang dan dagang.

Tuban, kota yang besar setelah majapahit, dengan kekutan gajahnya, kekutaan laut serta pasukan kataknya. Sehingga Tuban menjadi pusat perebutan dari dearah-daerah yang berada 
disekitarnya termasuk orang-orang peranggi. Kerajaan yang terletak di seluruh pantai utara jawa, Demak, Tuban, Blambangan, Pjajaran, dan Semarang yang dulunya adalah daerah kekuasaan Majapahit, setelah paca kejatuhan Majaphit, daerah tersebut mulai mendirikan pemerintahan sendiri-sendiri dengan sultan, atau Adipati secara otokrasi. Dua kerajaan yang paling menonjol dalam permusuhan adalah Demak dan Tuban.Setelah Tuban sudah kehilangan kesatriaannya, muncul Demak yang menjadi negeri yang kuat pasca keruntuhan Majapahit. Selain itu juga, Demak juga menjadi kerajaan Islam yang pertama di bumi Jawa. Hingga Demak mampu merebut jepara dari kekuasaan Tuban itu.

Demak memperkuat wilayahnya dengan membuat certbang-cetbang, serta aramada kapal lebih banyak diciptakan. Dan mempeluas wilayahnya, seperti jepara yang dulunya adalah daerah kekuasaan Tuban sekarang menjadi daerah jarahan Demak. Semua itu adalah misi Demak untuk menyebarkan Agamanya.

Hal ini juga disampaikan Foucault, bahwa dalam rangka untuk melakukan tindakan represif itu, negara membangun tekonologi kuasa dalam rangka melakukan pendisiplinan tubuh warga negaranya. Penghukuman dalam konteks itu dipandang sebagai strategi yang efektif untuk melakukan penaklukan atas tubuh-tubuh warga negara itu. Bahkan, dalam konteks represivitas negara terhadap warga negara, negara tidak jarang berada dalam bangunan panoptikon, yakni melakukan seluruh daya untukmelakukan kontrol terhadap warga negaranya (Foucault, 1997:162).

Demak sudah membangun kekutan politiknya baik laut, daratnya. Demak sydah semakin kuat dimata Tuban. Dengan kehilagan satu wilayah yaitu Jepara beserta bandarnya. Tuban hanya mengimbangi tanpa ada balasan atau merebut kembali daerah kekuasaannya. Bahkan menurut Adipati perang tidak diperbolehkan Agama.

Ada yang menyalahkan Tuban yang jelas-jelas telah mengkhianati janji. Dalam pelayaran menuju jepara, ia kaji semua alasan yang didengarkan dan membenarkan semua. Tetapi juga membenarkan: Adipati Unus satu-satunya orang yang berani berusaha mempersatukan kekuatan melawan Portugis, dan berani melaksanakan peperangan. Kekalahan yang terjadi bukan kekalahan perang, tetapi kekalahan dalam mengatur kekuatan sendiri. Kemudian ia menyimpulkan: armada gaubungan semestinya tidak kalah (Toer, 1995:195).

Ketika sang Adipati Tuban mendengar peranggi menahklukan Malaka dan armada penjajah itu sering berkeliaran di laut Nusantara, sang Adipati menyimpan hasrat untuk berbaikbaik dengan peranggi, yang sangat mengigingkan remaph-rempah di gugusan pulau Jawa, terutama Maluku. Dalam pemikiran Adipati, pelabuhan bebas Tuban dapat disinggahi atau dapat dijadikan tempat bersandar untuk mengambil rempah-rempah dari Jawa. Dan urusan dangang dengan peranggi akan memberikan keuntungan besar bagi Tuban.

Demikian sang Adipati Tuban. Yang didorong kegairahan untuk menjalin hubungan dengan perangi, ia memutuskan untuk memecat syahbandar Tuban Iskaq Indrajit dan mengangkat Sayid Habibullah Almawasawa yang dapat menguasai bahasa Arab, peranggi, dan Senpanyol untuk memudahkan misi politik dan dagangnya. Iskaq Indrajit kecewa dan iri hati dengan keputusan Adipti. Kemudian oleh sang Adipati diberi kekuasaan untuk menjadi bupati di lima daerah pedalaman Tuban. Disinilah Ishak membangun dan meluaskan pengaruhnya dengan memperalat Islam. 
Perubahan demi perubahan serta intrik politik, penghiatan, dan keirian hati menjadikan bumi Jawa terutama Tuban semakin terpuruk dengan datangnya orang asing, orang-orang peranggi. Hal yang menonjol adalah peralihan dari Hindu-Budha beralih ke agama Islam.

Meski Malaka sudah jatuh ke tangan portugis. Justru sang Adipati ingin membangun kerjasama dengan orangorang pernggi. Hal ini juga di buktikan dalam penyerangan ke Malakan. Demak, Jepara dengan kekuatan armada laut serta pasukannya mendatangi Malaka untuk menyerang dan merebut kembali bandar yang kunci perdangangan Asia. Begitu juga Gususan tuban, yang dengan kesengajaan Adipati memberangkatkan pasukan dengan keterlembatan yang disengaja.

Sang Adipati Tuban telah dengan sengaja memperlambat keberangkatan untuk tidak menyertai perang di Malaka. Sebaliknya Jepara kini telah merampas gugusan Tuban, kapal dan anak buahnya dan prajuritnya, termasuk dirinya. Ia harus selamatkan gugugsan Tuban (Toer,1995:194).

Bagaimana sikap Sang Adipati yang denga sengaja memberangkatkan pasukan Tuban dengan keterlembatan. Jelas, misi politik Adipati serta ketidak senangan dengan peperangan. Hal ini juga dosebutkan oleh Pram dibawah ini.

Tuban sebaliknya, membiarkan dirinya mengulur-ngulur waktu untuk memperlihatkan diri untuk dapat memukul Demak dengan jalan lain dan cara lain. Ia pernah mendengar, sang Adipati tidak menyukai perang (Toer, 1995:195).

Putikan di atas menyebutkn dimana sang Adipati telah bersikap serta tidak menghendaki adanya peperangan pada gugusan Tuban. Smentara Demak sudah bersiap untuk melakukan penyerangan ke Malaka.

Adipati Unus satu-satunya orang yang berani mempersatukan kekuatan melawan Portugis, dan berani melakukan penyerangan. Kekalahan yang terjadi bukan kekalahan perang, tetapi kekalahan dalam mengatur kekuatan sendiri. Kemudian ia menyimpulkan: armada gabungan itu semestinya tidak kalah. Ia mengaguk-ngaguk mengerti (Toer, 1995:206).

Dipelaubuhan-pelabuhan itulah, terutama di Jeapara, dipersenjatai armada-armada yang beberapa kali dilancarkan oleh jawa dengan harapan bisa merebut kemabli Malaka . serangan di adakan pada tahun 1512-1513 dibawah pati Unus, yang menurut sumber-sumber Portugis naik sebuah kapal dengan ukuran yang besar sekali, lalu pada tahun 1551 dn 1574 atas hasutan Ratu Kalimayat yang giggih itu, yang menjadi ratu Jeapara selam seperempat abad lebih (Lombord,2008:54)

Betapa gagahnya pasukan DemakJepara yang berani mendatangi peranggi di selat Malaka. Dan berani berperang melawan kekuatan peranggi. Sejarah yang tidak pernah terungkap. Disini New Historism mengukapkan teks-teks kanon atau teks yang termarjinalkan oleh pusat atau teks sejarah yang baku. Sesuai dengan teori poststrukturalisme dengan metode dekontruksi atau pembongkaran teks-teks.

Pramoedya mengukapkan bagaimana perwatakan jawa, serta intrik politik para pembesar kerajaan yang berada di sepanjang pesir-pesisr laut utara Jawa. Semua tidak luput dari kepentingan-kepentingan pribadi yang menjadi dasar pertikaian para pembesar kerajaan pesisir utara. Pertikaian demi pertikaian terjadi, hingga lupa akan sebuah persatuan dalam mempertahankan pulau Jawa ini. 
Demak juga membawa ancaman kepada Tuban pada saat pemerintahan Raden Patah. Walaupun Adipati Tuban mengirimkan anaknya, Raden Said alias sunan Klaijaga ke Demak untuk mempelajari agama Islam. Demak tetap saja menimbulkan ancaman. Dalam satu serangan, Jepara, sebuah kota pelabuhan dalam wolayah kekuasaan Tuban, berasil dikusai Demak. Di Jepara inilah, Adipati Unus, yang kemudian diangkat menjadi sultan Demak setelah kematian Raden Patah, membangun kekauata untuk membangun armada perang mnyerang peranggi di Malaka.

Perangi yang datang dari Atas Angin dan sudah bercokol di Malaka coba diserang tentara Demak di bawah pimpinan Adipati Unus. Tetapi malangnya Majapahit tidak tidak dapat mengatasi kehebatan meriam peranggi. Misi itu hancur, Adipati Unus mengalami luka parah dan di bawa pulang ke Demak dalam keadaan hampir mati. Misi serangan terhadap perangi ini coba dilanjutkan oleh Wiranggaleng selepas kematian Adipati Unus. Tetapi teknologi senjata perangi yang lebih unggul dibandingkan dengan senjata pribumi Nusantara yang masih kuno, menyebabkan misi itu kembali mengalami kegagalan. Disana, Pramoedya menegaskan, bahwa pribumi, yaitu jawa dan Malaka kalah oleh kekuasaan asing. Dia memaparkan sebagai berikut.

"untuk kedua kali aku bilang, aku tetap dibelakangmu, kang. Katakan semua padaku. Aku tahu aku kalah untuk kedua kalinya untuk merebut Malaka. Semua orang tahu. Katakanlah, curahkan semua duka citamu kang."

Lama Wiranggaleng tak bicara, lambat: berat, sepatah-patah:

"hampir-hampir aku tak dapat menahan perasaanku, pada. Aku hanya si anak desa yang tersasr ketempat yang belum tujuannya. Hampir lima belas tahun yang lalu semestinya peranggi telah terusir dari sini. Sekarang mereka lebih kuat. Kita lebih lemah, pada. Tak ada nama yang begitu terbenci dalam hidupku yang satu itu: Trenggono, sultan Demak. Ia telah menjerumuskan Jawa dalm peperangan melawan yang bukan musuh. Dan membiarkan musuh semakin kuat begini. Ia telah terhamba orang-orang serumah sendiri sedang diluarnya orang telah merampas dan mengusai sumber kehidupan (Toer,1995:639).

Pramoedya kekalahan pribumi bersaal dari dari kelemahan sendiri. Salah satu kelemahan adalah perselisihan dasar lama dengan dasr baru. Dia menjelaskan sang Adipati Tuban menghendaki dasardasar lama tidak berubah, ragu-ragu terhadap yang baru, sedangkan yang lama terus menerus mendesak. Yang lama denga segala keuntungan dan keamanannya tidak bisa dipertahankan sambil menerima keuntungan tambahan dari yang baru, dan itu yang Gusti Adipati tidak bisa terima.

"kita masih dapat mengingatkan betapa mengirimkan gugusan pasukan laut kejepara dengan waktu yang sengaja ditidaktepatkan. Penyerangan atas Malaka gagal, hancur, hancur, kalah. Kita semua mendapatkan malu. Apapun yang telah diperbuat Demak terhadap Tuban, Adipati Jepara benar, sang Adipati melepaskan guusan Tuban untuk memberikan pukulan berliapat atas Demak, tetapi Tuban sendiri yang rugi. Malaka tidak jatuh, peranggi tetap berdiri, dan bandar Tuban seperti bandarbandar lain diseluruh Jawa (Toer, 1995:320).

Pramoedya sangat keberatan terjadinya arus balik, dari selatan ke utara. Dan sekarang berbalik dari utara ke selatan. Hakikat ini do gambarkan dalam novel sebagai berikut. 
Sekarang makin lama makin sedikit kapal-kapal jawa berlayar ke utara, ke atas angin, ke Campa ataupun ketiongkok. Kapal dari selatan mulai tipis. Sebaliknya arus utara semakin deras, membawa barang-barang baru, pikiran-pikiran baru. Juga ke Tuban (Toer, 1995:23).Hal itu juga disebutkan Denys Lombard, tindakan itu menunjukan kepercayaan China terhadap sekutunya dan sekaligus peran Jawa (Majapahit) sebagai pusat persimpangan jaringan niaga Asia (Lombard, 2005:41). Ada sebuah gambaran bahwa Malaka sebagai pusat bandar dari negaranegara sebrang, sampaidengan Majapahit yang telah memparkasai tongak jaringan atas bangsa-bangsa. Malaka sebagai peran yang sangat penting dalam perdangangan maritim Asia Tenggara. Ada beberapa jaringan niaga yang telah dibangun pada abab ke 16 oleh selat Malaka. Tome Pire yang pernah tinggal di malaka pada tahun 1512-1515 mendiskripsikan 10 trayek pelayaran yang menghubungkan dan dihubungkan oleh Malaka pada abad ke-16, sebagai komoditi dagangnya,

1. Malaka-pantai timur sumatra: emas, kapur barus, lada, sutra, damar, dan hasil hutan lainya, madu, lilin, tir belerang, besi, kapas, rotan, serta bahan-bahan pangan lainnya dan budak. Hasil-hasil itu di tukar dengan tekstil india. Jung-jung perdagangan juga dibeli di malaka oleh para pedagang dari beberapa daerah.

2. Malaka-Sunda (jawa Barat); lada asam jawa, budak, emas, dan bahanbahan perdagangan lainnya. Hasinya ditukar dengan tekstil india, pinang, air mawar, dan sebgainya.

3. Malaka-Jawa Tengah dan Jawa Timur; beras dan bahan-bahan pangan lainnya, lada, dan tekstil yang dimanfaatkan sebagai barang dagangan yang lebih jauh ke Timur.
Hasil-hasil ini di tukar dengan tekstil india yang baik mutunya dan barangbarang China.

4. Jawa Barat-pantai Barat Sumatra; hasil yang dengan hasil dari pantai timur Sumatra dan kuda dikapalkan ke Jawa Barat. Terjadi pula perdangan secara langsung dengan para pedagang Gujarat yang membawa tekstil.

5. Jawa Tengah dan Jawa TimurSumatra Selatan; kapas, madu, lilin, tir, rotan, lada, dan emas di kapalkan ke Jawa.

6. Jawa-Bali, lombbok, Sumbawa; bahan-bahan pangan, tekstil kasar, budak, dan kuda. Hasil-hasil ini ditukarkan dengan dengan tekstil kasar jawa.

7. Bali, Lombok, Sumbawa-Timor; kayu cendana dari daerah-daerah timor dn snba ditukarkan dengan tekstil kasar india dn jawa.

8. Timor, Sumba-Maluku; pala, cengkeh, dan bunga pala dari maluku ditukarkan dengan tekstil kasar Sunbawa, mata uang jawa, dan perhiasan india.

9. Jawa dan Malaka-Kalimantan selatan; bahan-bahan pangan, intan, emas, dan kapur barus ditukarkan dengan testil india.

10. Sulawesi selatan-Malaka, jawa barat, brunei, Siam, Semenjung Malaya; budak, beras, dan emas dari makasar dutukarkan lansung oleh orang-orang Bugis dengan tekstil India, damar, dan sebagainya, Ricklefs dalam (Hamid, 2015:96-97).

Sistem perdangan tersebut duhubungakn di Malaka dengan jalurjalur yang membentang: ke Barat sampai India, Persia, Arab, Syiria, Afrika Timur, dan laut Tengah: ke utara sampai Siam dam Pegu: ke timur sampai China dan mungkin Jepang. Ini merupakan sistem perdangangan yang paling besar di dunia 
pada amannya. Dua tempat yang paling penting adalah Gujarat(india barat laut) dan Malaka. Rempah-rempah merupakan komoditi utama, kemudian tekstil India dan beras Jawa (Abdrahman Hamid, 2015:97).Selain itu juga Pramoedya mengangap laut lebih penting peranannya dari pada darat bagi Nusantara. Dia juga menkelaskan bahwa hanya tanah, seluruh alam diserahkan oleh Allah pada manusia. Kalau orang tidak tau artunya alam, inilah dia.Semua-semua saja kecuali Allah sendiri. Tanah ini, Jawa ini, kecil, lautnya besar. Barang siapa kehiangan air, dia kehilangan tanah, barang siapa kehilangan laut dia kehilangan darat (Toer,1995:223).Pada awal abad ke 16, kekautan pemersatu kerajaan Majapahit telah patah. Para gubenur pesisir telah memungungi Majapahit, sehingga runtuh dan berdiri sendiri-sendiri, jadi raja-raja kecil, tanpa ada yang berani mengangakat diri jadi kaisar. Juga bupati Tuban sang Adipati Arya Teja Tumenggung Wilwatikta. Orang tua hanya berbisik-bisik berani membicarakan dengan sesama tua, tak lain dari sang Adipati juga yang memprakarsai dan memimpin persekutuan rahasia ini, Majapahit jatuh.

Majaphait telah lama jatuh, disewrang olej baa tentara Demak, yang dalam peperangan disemangatai oeh pidato-pidoato sunan kudus yang menaykinkan (Lombord,2008:57).

Dalam pada itu Pramoedya memperlihatkan kesannya yang negatif terhadap orang-orang asing, khususnya orang kulit putih yang selalu berbuat jahat. Pramoedya menagakatakan.

Wiranggaleng untuk pertama kali orang kulit putih dari dekat pada waktu dia ikut iring-iringan orang asing terhapadap sang Adipati. Tokoh ini mengaggap bahwa muka mereka kemerah-merahan seperti jambu bol, langkahnya panjang-panjang dan tetap tegap, bebas bicara dengan yang lain. Sehingga dia tak tau pasti mana kepala dan mana bawahan. Mereka tidak melakukan sembah menyembah. Seluruh badan dari leher sampai muka dari pergelangan tangan sampai jari-jari terbuka. Semua tertutup dan keringat nampak membasahi pungung mereka . sebentar-sebentar menyeka keringat lehar dengan sepotong kain, kemudian memasukannya kedalam saku baju. Dan mereka bicara satu pada yang lain nampak tak mengindahkan orang selebihnya (Toer,1995:211)

Pesan Pramoedya pada novel ini, adalah mencoba memberi penyadaran tentang masa depan bangsa yang cerah. Menurut hemat penulis, waktu itu hanya ada dua kerajaan, yaitu kaisar tiongkok di utara dan Raja Majapahit di selatan yang begitu besar perhatiannya pada nasib bangsa sendiri. Oleh karena itu, dia menaruh perhatian terhadap nasip bangsa sendiri. Oleh karena itu, dia menaruh perhatian terhadap masa depan keturunannya, yang dipaparka sebagai berikut.

Makin malam makin riuh pergolakan dalam dirinya. Bukan bayangan yang memburu-buru, bukan rusa bukan kijang, tapi tanya dan duga yang tiada putus-putusnya. Bagaimana mereka jadinya dalam sepeuluh tahun mendatang? Apakah serba kebalikan daripada impian Rama Cluring impianku pribadi? Bagaimana bakalnya nasib Gelar dan Kumbang? Apakh mereka akan lebih buta dan lebih tidak berdaya, tidak berkemampuan, daripada aku? Apakah meeka hanya akan jadi korban kesia-sian raja-raja yang dungu? (Toer,1995:516)

Harapan dan semangat untuk memajukan bangsa sendiri penting sekali bagi Pramoedya yang selama ini beranggapan bahwa tidak ada tanda-tanda kebesaran dan kejayaan yang dapat dipanggil dari gua garba masa depan, dan 
memikirkan bahwa yang ada hanyalah kekosongan yang menganga, bolong dan melompong.

Sebagaimana yang telah ditulis dalam sejarah, kaerajaan Demak dilukiskan sebagai kerajaan yang kokoh dan kuat daripada Banten. Banten sidah jatuh kedalam keauasaan Demak. Pada zaman itu, yaitu awal abad ke 16, kerajaan Demak sudah memeluk agama islam secara keseluruhan, sedangkan kerajaa Tuban hanya setengah negeri islam. Sehubungan kedatangan islam ke tanah rantau Jawa, peranan yang mainkan oleh beberapa orang Arab disentuh oleh Pramoedya. Secara kebetulan atau tidak, juga dingatkan pada sifat yang kurang jujur dari beberapa orang arab. Misalnya mantan Syahbandar Malaka sebelum kerajaan itu jatuh ke dalam tangan orang peranggi, dikatakan menipu Sultan Mahmud dan lari dari kota itu sampai ke pulau Jawa dengan berbagai nama samaran. Perilaku itu seperti tidak disukai oleh orang Jawa, sehingga ia digambarkan sebagai si cerewet. Selain iu juga, salah satu pendapat yang sering diutarakan ialah bahwa orang arab tampaknya terlalu dekat denag orang peringgi dan tidak mementingkan orang jawa.

Dalam Novel Arus Balik, Bagiamana Pramoedya mengambarkan sistem kemaritiman yang digunakan oleh kerajaan-kerajaan besar seperti halnya Majapahit. Pramoedya dalam gelombang maritim juga mengambarkan dalam Novelnya yang berlatar abad ke 16 itu dengan gambaran perwatakanperwatakan baik dari Jawa, Arab, China, dan Eropa. Segala macam peralihan kebudayaan yang telah melingkupi Bumi Jawa Nusantara ini. maka dari situlah bahwa karya sastra merupakan dokumen sosial yang telah di gambarkan oleh Pramoedya Ananta Toer.

\section{DAFTAR PUSTAKA}

Barry, Peter. 2010. Pengantar Komprehensif, Teori satar dan Budaya. Yogyakarta. Penerbit Jalasutra

Foucault. 2011. Pengetahuan dan Metode. Penerbit. Jalasutra.

Hamid. 2015. Sejarah maritim Indonesia. penerbit. Ombak.

Hun. 2011. Melacak jejak Indonesia. Anggota IKAPI. Penerbit PT Gramedia Pusataka Utama.

Lombord. 2008. Nusa Jawa: Silang Budaya. Jilid 2. Alih Bahasa: Winarsih Partaningrat Arifin. Rahayu S. Hidayat. Penebit PT. Gramidia Pustaka Utama.

Nyoman. 2010. Sastra dan Cultural Studies Resepsi Fiksi dan Fakta. penerbit. Pustaka Pelajar.

R. Soeparmo. Catatan sejarah 700 Tahun Tuban. Perpustakaan Tuban.

Teeuw. 2003. Sastera dan Ilmu sastera. Penerbit PT Dunia Pistaka Jaya

Toer. 2002. Arus Balik. Penerbit Hastra Mitra 